\title{
PEQUI FLOUR APPLIED IN THE PREPARATION OF FOOD PASTA ${ }^{1}$
}

\author{
RENATA NOLASCO BRAGA-SOUTO ${ }^{2 *}$, THALITA CORDEIRO SANTOS ${ }^{2}$, GABRIEL \\ STHEFANO LOURENÇO PEREIRA ${ }^{3}$, MARIUZE LOYANNY PEREIRA OLIVEIRA ${ }^{2}$, \\ CLAUDIA REGINA VIEIRA ${ }^{2}$, JULIANA PINTO DE LIMA ${ }^{2}$
}

\begin{abstract}
Pasta products are generally formulated based on wheat flour, and the insertion of other vegetable raw materials, such as pequi fruit, can provide increased nutritional value, along with differentiated technological and sensory characteristics. Thus, the aim of this study was to produce pasta with different levels of substitution of wheat flour with pequi pulp flour, to determine its proximate composition and to evaluate its technological and sensory properties. Pastas were produced with 5\%, 10\% and 15\% of wheat flour being substituted by pequi pulp flour, and there was also a control group. Technological analyses (cooking time, volume expansion, water absorption, cooking loss, color difference and chromaticity), chemical analyses (moisture, ash, lipids, proteins and total carbohydrates) and sensory tests (acceptance and intention consumption) were carried out. The main results showed that pequi flour promoted an expansion in volume and water absorption in the product; raw and cooked pasta had more intense colors; moisture, ash and lipid content was increased by using pequi flour; and the sensory test scores for the samples with pequi were high in relation to the control samples, with the formulations with the highest content of pequi flour being the best evaluated. It is concluded that the pastas with pequi flour are promising products for the food industry.
\end{abstract}

Keywords: Caryocar brasiliense. Noodles. Nutritional composition. Technological evaluation. Sensory analysis.

\section{FARINHA DE PEQUI APLICADA NA ELABORAÇÃO DE MASSAS ALIMENTÍCIAS}

\begin{abstract}
RESUMO - Massas alimentícias são geralmente formuladas a base de farinha de trigo, sendo que a inserção de outras matérias-primas vegetais, como o fruto pequi, pode proporcionar incremento de valor nutricional, características tecnológicas e sensoriais diferenciadas. Dessa forma, o objetivo desse estudo foi produzir massas alimentícias com diferentes substituições da farinha de trigo por farinha da polpa de pequi, determinar a sua composição centesimal e avaliar as propriedades tecnológicas e sensoriais das massas elaboradas. As massas alimentícias foram produzidas com substituições de 5\%,10\% e 15\% da farinha de trigo pela farinha da polpa de pequi, além do grupo controle. Foram realizadas análises tecnológicas (tempo de cozimento, expansão de volume, absorção de água, perda de sólidos solúveis, diferença de cor e cromaticidade), análises químicas (umidade, cinzas, lipídios, proteínas e carboidratos totais) e testes sensoriais (aceitação e intenção de consumo). Os principais resultados mostrados foram que a farinha de pequi promoveu expansão no volume e na absorção de água no produto; massas cruas e coccionadas apresentaram cores mais intensas; incrementou-se os teores de umidade, cinzas e lipídios pelo uso da farinha de pequi; e as notas dos testes sensoriais das amostras com pequi foram elevadas em relação às amostras controle, sendo as formulações com maiores teores de substituição de farinha de pequi as melhores avaliadas. Conclui-se que, as massas alimentícias com farinha de pequi são produtos promissores para a indústria alimentícia.
\end{abstract}

Palavras-chave: Caryocar brasiliense. Macarrão. Composição nutricional. Avaliação tecnológica. Análise sensorial.

\footnotetext{
${ }^{*}$ Corresponding author

${ }^{1}$ Received for publication in $06 / 11 / 2020$; accepted in 01/28/2021.

Paper extracted from the research of the Study Group on Bakery and Pasta Products.

${ }^{2}$ Institute of Agricultural Sciences, Universidade Federal de Minas Gerais, Montes Claros, MG, Brazil; rnb.nolasco@gmail.com - ORCID: 0000-0001-6965-3411, cordeirothalita@yahoo.com.br - ORCID: 0000-0003-0443-2110, mariuzelpe@yahoo.com.br - ORCID: 0000-0002 -9441-3054, crvieira@ica.ufmg.br - ORCID: 0000-0002-9054-3361,juliana-pinto-lima@ica.ufmg.br - ORCID: 0000-0003-2182-8520.

${ }^{3}$ Faculty of Food Engineering, Universidade Estadual de Campinas, Campinas, SP, Brazil; gabrielsthefano.sthefano@gmail.com - ORCID: 0000-0003-1549-9054.
} 


\section{INTRODUCTION}

Pastas are obtained by using wheat flour and/ or flour derived from other cereals, legumes, roots or tubers, and result from a mechanical kneading process; when these pastas contain only wheat flour, they can be called pasta (noodles), and are called "mixed" when they contain wheat flour and other flours of vegetable species (BRASIL, 2005b). When vegetable flours are applied, in addition to the usual wheat flour, it is possible to increase the nutrient content of pasta; studies have shown an increase in the content of dietary fiber, ash, protein and lipids in pasta to which chia, amaranth and corn pericarp flour is added, for example (JUNQUEIRA et al., 2017; OLIVEIRA et al., 2015; SANTOS et al., 2015). Recent studies have exposed the importance of creating pasta with functional properties such as antioxidant activity, a reduction of the glycemic response and a reduction of oxidative stress (KHAN et al., 2015; LU et al., 2018; PASQUALONE et al., 2016). As for the technological quality of the pasta, products with a fast starch gelatinization capacity, low cooking losses, and high mass and volume yields are expected (DEL BEM et al., 2012; FERREIRA et al., 2016; KRISHNAN et al., 2012; OLIVEIRA et al., 2015; PADALINO et al., 2015; PIWINSKA et al., 2015).

Therefore, in view of the objectives of producing pasta with nutritional wealth and technological qualities, a fruit that can be processed into flour and used in these products is pequi (Caryocar brasiliense), typical of the Cerrado (PINTO et al., 2016). Its fresh mesocarp (pulp) in natura has a considerable content of ash $(0.67 \%$ to $0.70 \%)$, lipids $(13.54 \%$ to $26.15 \%)$, proteins $(1.94 \%$ to $3.73 \%)$ and fiber $(8.28 \%$ insoluble fiber and $3.11 \%$ soluble fiber) (ALVES et al., 2014; RIBEIRO et al., 2014). Fresh pequi is a source of iron and phosphorus, and presents a high content of copper, zinc and magnesium, minerals that are essential for proper functioning of the human body (ALVES et al., 2014; BRASIL, 2005c, 2012; GONÇALVES et al., 2011). In addition, the pulp has a rich fatty acid profile, which consists of $51.10 \%$ to $64.63 \%$ monounsaturated fatty acids, with an emphasis on oleic acid, and $11.50 \%$ to $16.90 \%$ polyunsaturated fatty acids, with a predominance of linoleic acid (RIBEIRO et al., 2014). This unsaturated fraction is related to human health, through the prevention or reduction of the risks of coronary problems and metabolic disorders (FARVID et al., 2014; MOREIRA et al., 2016; THANDAPILLY et al., 2017). This lipid fraction also contains dissolved carotenoid pigments (MENDONÇA et al., 2017), such as $\beta$-carotene and $\beta$-cryptoxanthin, which are precursors of vitamin A (CARDOSO et al., 2013).

Nascimento et al. (2017) produced flour from this fruit through freeze-drying of the pulp, obtaining a product with a high concentration of nutrients. In addition, studies on the sensory evaluation of products made using pequi have obtained good acceptance, the preferred or better evaluated formulations being those with the highest concentrations of pequi (ANDRADE et al., 2009; RODRIGUES et al., 2016), results that reinforce the possibility of developing food with this fruit.

In this sense, the research aimed to produce pasta with different levels of partial substitution of wheat flour with pequi pulp flour $(5 \%, 10 \%$ and $15 \%)$, determine its proximate composition and evaluate its technological and sensory properties.

\section{MATERIAL AND METHODS}

The study was conducted at the Plant Products Technology Laboratory and at the Food Technology Laboratory of the Instituto de Ciências Agrárias (ICA) of the Universidade Federal de Minas Gerais (UFMG). For preparation of the formulations, ingredients were obtained from the local market in Montes Claros, paying attention to the expiration date and integrity of the packaging. The pequis came from the same municipality in the 2016/2017 harvest.

\section{Pequi flour production}

Ripe, healthy and injury-free fruits were used. These fruits were washed in running water, brushed and left in $100 \mathrm{mg} \mathrm{L}^{-1}$ sodium hypochlorite solution for $30 \mathrm{~min}$, and then bleached in water at $90^{\circ} \mathrm{C}$ for 5 min. After cooling in an ice bath, the pyrenes and the pulp of the pequis were removed manually.

The pulp was sanitized in $50 \mathrm{mg} \mathrm{L}^{-1}$ sodium hypochlorite solution for $30 \mathrm{~min}$, then fragmented and dehydrated in a dryer with air circulation at $60^{\circ}$ $\mathrm{C}$ for $6 \mathrm{~h}$, followed by cooling to room temperature. The initial moisture content of the pequi pulp was $62 \%$, and the moisture content of the flour was $15 \%$ after the pulp dehydration process was completed. Then, the dehydrated material was ground in a domestic multiprocessor (Philips Walita model RI $7625)$, placed in a hermetically sealed amber glass container and stored at $7{ }^{\circ} \mathrm{C}$ for $48 \mathrm{~h}$ until its application in the production of pasta.

\section{Pasta making}

Four formulations were elaborated (Table 1), one being the control (without pequi flour) and three with partial substitution of wheat flour with pequi flour $(5 \%, 10 \%$ and $15 \%)$. The preparation started by mixing and homogenizing the ingredients in an electric mixer; afterwards, the pasta was manually 
shaped, stored in the refrigerator for $10 \mathrm{~min}$ and passed in a cylinder until a thickness of $3 \mathrm{~mm}$ was reached. Then, the pasta was cut into strips $5 \mathrm{~mm}$ wide by $120 \mathrm{~mm}$ long. Subsequently, the fresh pasta was dried in an oven with air circulation at $60^{\circ} \mathrm{C}$ for $5 \mathrm{~h}$, packed in low density polyethylene bags and stored at $7{ }^{\circ} \mathrm{C}$.

Table 1. Pasta formulations.

\begin{tabular}{ccccc}
\hline Formulation $(\%)$ & Control & $\mathrm{P}^{1}$ & $\mathrm{P} 10^{1}$ & ${\mathrm{P} 15^{1}}^{1}$ \\
\hline Wheat flour $(\mathrm{g})$ & 85.00 & 80.75 & 76.50 & 72.25 \\
Pequi flour $(\mathrm{g})$ & 0.00 & 4.25 & 8.50 & 12.75 \\
Pasteurized egg $(\mathrm{g})$ & 2.50 & 2.50 & 2.50 & 2.50 \\
Salt $(\mathrm{g})$ & 1.00 & 1.00 & 1.00 & 1.00 \\
Oil $(\mathrm{mL})$ & 3.00 & 3.00 & 3.00 & 3.00 \\
Water $(\mathrm{mL})$ & 35.00 & 35.00 & 35.00 & 35.00 \\
\hline
\end{tabular}

${ }^{1}$ The number after the letter $\mathrm{P}$ indicates the percentage $(5 \%, 10 \%$ and $15 \%)$ substitution of wheat flour with pequi flour in pasta.

\section{Centesimal composition}

The analyses used to determine the proximate composition of the cooked pasta at the optimum cooking time were based on the Official Methods of Analysis (AOAC, 2016), with the exception of the analysis of lipids (BLIGH; DYER, 1959). To quantify proteins, the Kjeldahl method was used and the nitrogen conversion factor considered was 5.7. The amount of total carbohydrates was obtained by difference $[100 \%-(\%$ ash $+\%$ proteins $+\%$ lipids)]. The results were expressed on a dry basis.

\section{Cooking tests}

For technological tests of cooking time, volume expansion, water absorption and loss of soluble solids (cooking loss), the American Association of Cereal Chemists (AACC, 2000) methodology no. 16-50 was followed, with modifications.

\section{Cooking time}

Cooking time was determined by cooking 10 $\mathrm{g}$ of sample in $140 \mathrm{~mL}$ of distilled water; a small amount of mass was pressed between glass plates every $30 \mathrm{~s}$ until the white center disappeared (gelatinization of starch). This parameter was expressed in minutes of cooking.

\section{Volume expansion}

In beakers containing $50 \mathrm{~mL}$ of distilled water, raw pasta of each formulation was placed to measure the volume displacement; afterwards, the pasta was cooked for its optimal cooking time, and the displaced water volume was again measured. The volume expansion was given by the number of times the pasta expanded after cooking according to equation 1.

$$
\text { Volume expansion }=\frac{\text { Displaced volume }[\text { after cooking }]\left(\mathrm{cm}^{3}\right)}{\text { Displaced volume [raw] }\left(\mathrm{cm}^{3}\right)}
$$

\section{Water absorption}

Evaluation of the water absorption potential of the pasta was carried out by cooking it in $100 \mathrm{~mL}$ of boiling water for the optimal cooking time and subsequently draining excess water. The mass was measured before and after cooking the pasta to obtain the volume of water the product absorbed in relation to its initial mass through equation 2 .

$$
\text { Water absorption }=\frac{\text { Mass }[\text { after cooking }](\mathrm{g})}{\text { Mass }[\mathrm{raw}](\mathrm{g})}
$$

\section{Loss of soluble solids (cooking loss)}

From the water absorption analysis, $25 \mathrm{~mL}$ aliquots of the remaining cooking water were removed for drying in an oven at $105{ }^{\circ} \mathrm{C}$ in a measuring vessel until constant weight. The loss of soluble solids was obtained by equation 3 .

$$
\text { Loss of soluble solids }(\%)=\frac{\mathrm{VW} * \mathrm{mr} * 100}{\mathrm{va}^{*} \mathrm{mrp}}
$$

where $\mathrm{VW}=$ volume of water $(\mathrm{mL}) ; \mathrm{mr}=$ mass of the residue $(\mathrm{g})$; va $=$ volume of the aliquot $(\mathrm{mL})$; and $\mathrm{mrp}=$ mass of the raw pasta $(\mathrm{g})$.

\section{Color analysis}

The difference (equation 4) and the color saturation or chromaticity of the pasta before and after cooking (equation 5) were measured by a 
portable Konica Minolta colorimeter with the CIELAB system defined by the coordinates $\mathrm{L}^{*}$ (black/white coordinate), a* (coordinate red/green) and $b^{*}$ (yellow/blue coordinate).

$$
\text { Color difference }=\sqrt{(\Delta \mathrm{L})^{2}+\left(\Delta \mathrm{a}^{*}\right)^{2}+\left(\Delta \mathrm{b}^{*}\right)^{2}}
$$

where $\Delta \mathrm{L}^{*}=$ difference of the $\mathrm{L}^{*}$ coordinate before and after cooking; $\Delta \mathrm{a}^{*}=$ difference of the $\mathrm{a}^{*}$ coordinate before and after cooking; and $\Delta \mathrm{b}^{*}=$ difference of the $b^{*}$ coordinate before and after cooking.

$$
\text { Chroma }=\sqrt{\left(\mathrm{a}^{*}\right)^{2}+\left(\mathrm{b}^{*}\right)^{2}}
$$

\section{Sensory tests}

The sensory tests, consumption intention and acceptance, were conducted at the Food Technology Laboratory at ICA/UFMG, having previously been approved by the UFMG Human Research Ethics Committee (90758318.2.0000.5149).

The formulations prepared were cooked for their optimum cooking time (according to the results obtained in cooking tests); $100 \mathrm{~g}$ of pasta was cooked in $1.4 \mathrm{~L}$ of water with $7 \mathrm{~g}$ of salt, the only spice added, so that the perception of the real taste of the pasta would not be altered. Sixty untrained tasters were served the four samples on white plastic plates, coded with three numbers chosen at random, and a glass of water for use in the tasting interval of each sample. During the tests, the tasters also received an Informed Consent Form (ICF) for research with human beings and filled out a questionnaire to collect identification data, eating habits and knowledge about the product.

The consumption intention test was performed using a 7-point hedonic scale: from 1 "I would never eat", through 4 "I would eat occasionally" to 7 "I would always eat" (INSTITUTO ADOLFO LUTZ - IAL, 2008). The acceptance test evaluated how much the judges liked or disliked the characteristics of appearance, texture, flavor and global acceptance of the pastas through a 9-point hedonic scale: from 1 "I disliked extremely", through 5 "I neither liked nor disliked" to 9 "I liked extremely" (IAL, 2008).

\section{Experimental planning and statistical analysis}

The design chosen to conduct the experiment was completely randomized (CR), containing three replicates, and the data are presented as the mean \pm standard deviation. The results of chemical, technological and sensory analyses were analyzed statistically with Sisvar software, where they were subjected to analysis of variance (ANOVA), and to Tukey's test at $5 \%$ probability when significant (FERREIRA, 2011).

\section{RESULTS AND DISCUSSION}

\section{Centesimal composition}

Table 2 shows the percentage moisture in the dehydrated pastas, that is, before the cooking process in water, as well as the centesimal composition of the cooked pastas. It is noted that the moisture content of the raw pasta decreased as wheat flour was replaced by pequi flour, which may be due to the initial moisture content of these raw materials, and thus the highest moisture content was $8.28 \%$ (control pasta); followed by $7.06 \%$ (P5); and the lowest levels, $6.69 \%(\mathrm{P} 10)$ and $6.47 \%$ (P15), which were not significantly different from each other. This moisture content was slightly lower than that found in dehydrated noodle-type pasta containing dehydrated ora-pro-nobis, $10.47 \%$ (ROCHA et al., 2009); and in pasta with $30 \%$ of the solid ingredients being mixed flour with different levels of beans and rice in partial replacement of wheat flour, which ranged from $10.70 \%$ to $10.98 \%$ (MINGUITA et al., 2015). Moisture is a variable considered in food preservation; dehydrated products and those with a low moisture content, such as the pastas in this work, may have a longer shelf life because, for example, they do not have a high water content favorable for growth of microorganisms (REIS et al., 2017). Therefore, all the pastas produced in this work can have good storage stability.

The cooked pasta with the highest moisture content was the P10 treatment $(75.59 \%)$, which differed significantly from the control formulation $(72.32 \%)$, which had the lowest content. In the study by Howard, Hung and McWatters (2011), cooked pasta with substitution of $50 \%, 40 \%$ and $30 \%$ of semolina for peanut flour presented a moisture content of $63.41 \%, \quad 64.40 \%$ and $64.84 \%$, respectively, and in the sensory analysis performed, the evaluators considered that these had moisture levels close to the ideal. In the present study, the pasta produced showed a moisture difference of around $10 \%$ compared to the masses in the study by Howard, Hung and McWatters (2011), that is, they may possibly also have good sensory acceptance regarding moisture content. 
R. N. BRAGA-SOUTO et al.

Table 2. Moisture content of raw (uncooked) pastas and centesimal composition of cooked pastas (\%).

\begin{tabular}{ccccc}
\hline Composition $^{1,2}$ & Control & $\mathrm{P}^{3}$ & ${\mathrm{P} 10^{3}}^{3}$ & ${\mathrm{P} 15^{3}}^{\mathrm{c}}$ \\
\hline Moisture [raw pasta] (\%) $^{4}$ & $8.28 \pm 0.07^{\mathrm{a}}$ & $7.06 \pm 0.07^{\mathrm{b}}$ & $6.69 \pm 0.14^{\mathrm{c}}$ & $6.47 \pm 0.17^{\mathrm{c}}$ \\
Moisture [cooked pasta] (\%) & $72.32 \pm 0.56^{\mathrm{b}}$ & $73.74 \pm 0.13^{\mathrm{ab}}$ & $75.59 \pm 0.11^{\mathrm{a}}$ & $74.13 \pm 1.64^{\mathrm{ab}}$ \\
Ash (\%) & $0.82 \pm 0.05^{\mathrm{c}}$ & $0.95 \pm 0.02^{\mathrm{c}}$ & $1.28 \pm 0.03^{\mathrm{b}}$ & $1.86 \pm 0.08^{\mathrm{a}}$ \\
Lipids (\%) & $1.01 \pm 0.08^{\mathrm{b}}$ & $1.07 \pm 0.07^{\mathrm{b}}$ & $3.70 \pm 0.39^{\mathrm{a}}$ & $3.93 \pm 0.14^{\mathrm{a}}$ \\
Proteins (\%) & $9.38 \pm 0.55^{\mathrm{a}}$ & $10.70 \pm 0.87^{\mathrm{a}}$ & $11.30 \pm 0.80^{\mathrm{a}}$ & $10.19 \pm 0.82^{\mathrm{a}}$ \\
Total carbohydrates (\%) & 88.79 & 87.28 & 83.72 & 84.02 \\
\hline
\end{tabular}

${ }^{1}$ Different letters in the same row indicate a significant difference at $5 \%$ significance using Tukey's test. ${ }^{2}$ Values expressed as mean \pm standard deviation (except total carbohydrates); all results are on a dry basis (except the percentage of moisture). ${ }^{3}$ The number after the letter $\mathrm{P}$ indicates the percentage $(5 \%, 10 \%$ or $15 \%)$ substitution of wheat flour with pequi flour in pastas. ${ }^{4}$ Raw pasta is the pasta only dehydrated, before cooking in water.

Regarding the ash content, the percentage increased as greater additions of pequi flour were made to the pasta. The P15 treatment had a content $(1.86 \%)$ significantly higher than the values found in the other treatments, being more than twice as much as that evaluated in the control pasta $(0.82 \%)$. Such results are justified by the richness of mineral residue of pequi pulps, between $0.85 \%$ and $1.48 \%$ on a dry basis, as reported by Alves et al. (2014) and Cordeiro et al. (2013), while the wheat flour used in the formulations was type 1 , which should have a maximum of $0.80 \%$ ash on a dry basis (BRASIL, 2005a). Additionally, an interesting fact was exposed by Gonçalves et al. (2011) who reported that even after a long cooking time (40 min), pequi pulp remains as a source of minerals, highlighting that calcium, phosphorus, magnesium, manganese and sulfur are not leached into the cooking water. Therefore, it is suggested that the pastas in the present work can retain a large part of this mineral content of the pequi pulp, since the pulp used in the formulations was in the dehydrated form (higher concentration of nutrients), and the longest cooking time $(13.33 \mathrm{~min})$ is short in relation to the maximum cooking time of the pulp so that it remains a source of minerals.

The substitution of $10 \%$ and $15 \%$ of wheat flour with pequi flour caused an increase in the lipid content in the pasta, and these treatments, P10 (3.70\%) and P15 (3.93\%), did not differ statistically from each other and resulted in a higher lipid content than treatment P5 (1.07\%) and the control (1.01\%), which presented statistically equal values. From the nutritional point of view, this elevation of the lipid content is important, because it is known that the lipid fraction of pequi is rich in unsaturated fatty acids and may contain $56.98 \%$ oleic acid (omega 9) and essential fatty acids, with $3.48 \%$ linoleic acid (omega 6) and 2.09\% linolenic acid (omega 3) (AGUILAR et al., 2012). Regarding these fatty acids, the literature addresses some of their functionalities, such as preventing metabolic disorders and improving heart health when consuming foods with high levels of oleic acid (MOREIRA et al., 2016; THANDAPILLY et al., 2017); reduced risk of coronary heart disease correlated with consumption of linoleic acid (FARVID et al., 2014); and the participation of linolenic acid in brain development to control cognitive functions (GRAYSON et al., 2014).

The formulations did not differ statistically in terms of protein content. An explanation is the possible similarity that can be found between the protein content of wheat flour on a dry basis, from $12.47 \%$ to $16.83 \%$ (CHANG; FLORES, 2004; VIEIRA et al., 2015), and the pulp of pequi on a dry basis, which can vary from $5.02 \%$ to $14.70 \%$ (ALVES et al., 2014; RIBEIRO et al., 2014) depending on edaphoclimatic conditions, which influence the composition of the fruit.

The percentage of total carbohydrates was high for all treatments, and this characteristic is common in pastas. In the literature, the content of this component varies between $73.07 \%$ and $86.67 \%$ (dry basis) in uncooked dehydrated pastas (FERREIRA et al., 2016; OLIVEIRA et al., 2015; ROCHA et al., 2009). It is noticed that this value is directly related to the increase in the products' lipid content, since the control and P5 formulations had the highest levels of total carbohydrates, $88.79 \%$ and $87.28 \%$, respectively, and also the lowest levels of lipids; and formulations $\mathrm{P} 10$ and $\mathrm{P} 15$ had lower amounts of total carbohydrates, $83.72 \%$ and $84.02 \%$ respectively, and the highest amounts of lipids.

It is also important to mention that within this fraction of total carbohydrates is dietary fiber, and the pequi pulp has a high content of this nutrient (from $7.99 \%$ to $14.06 \%$ on a wet basis) according to the studies by Cordeiro et al. (2013) and Ribeiro et al. (2014) and based on the Technical Regulation on Complementary Nutritional Information (BRASIL, 2012). Fiber has local benefits such as the control of 
gastrointestinal and systemic functions, for example, the reduction of obesity, postprandial glycemia, blood pressure and serum cholesterol levels, modulation of the intestinal microbiota and the prevention of cancer (CUI et al., 2019; FULLER et al., 2016; HAN et al., 2017; KORCZ; KERÉNYI; VARGA, 2018).

\section{Cooking tests}

Table 3 shows the results for the technological properties of pasta: cooking time, volume expansion, water absorption, cooking loss, color difference and chroma of the raw and cooked pasta.

Table 3. Technological properties of pastas: cooking time ( $\mathrm{min}$ ), volume expansion, water absorption, loss of soluble solids $(\%)$, color difference and chroma of raw and cooked pasta.

\begin{tabular}{ccccc}
\hline Parameter ${ }^{1,2}$ & Control & $\mathrm{P}^{3}$ & ${\mathrm{P} 10^{3}}^{3}$ & $\mathrm{P}^{3}$ \\
\hline Cooking time (minute) & $7.39 \pm 0.35^{\mathrm{c}}$ & $11.67 \pm 0.58^{\mathrm{b}}$ & $13.33 \pm 0.58^{\mathrm{a}}$ & $13.06 \pm 0.10^{\mathrm{a}}$ \\
Volume expansion & $3.48 \pm 0.22^{\mathrm{b}}$ & $3.73 \pm 0.25^{\mathrm{ab}}$ & $4.03 \pm 0.06^{\mathrm{a}}$ & $3.98 \pm 0.03^{\mathrm{a}}$ \\
Water absorption & $3.08 \pm 0.25^{\mathrm{c}}$ & $4.64 \pm 0.16^{\mathrm{b}}$ & $5.08 \pm 0.10^{\mathrm{a}}$ & $4.01 \pm 0.06^{\mathrm{c}}$ \\
Loss of soluble solids (\%) & $5.91 \pm 0.45^{\mathrm{c}}$ & $9.55 \pm 0.10^{\mathrm{b}}$ & $11.00 \pm 0.66^{\mathrm{a}}$ & $10.04 \pm 0.65^{\mathrm{ab}}$ \\
Color difference & $8.74 \pm 0.46^{\mathrm{c}}$ & $15.73 \pm 0.21^{\mathrm{a}}$ & $15.09 \pm 0.27^{\mathrm{a}}$ & $13.59 \pm 0.29^{\mathrm{b}}$ \\
Chroma (raw pasta) & $17.99 \pm 0.20^{\mathrm{c}}$ & $45.92 \pm 0.83^{\mathrm{b}}$ & $45.27 \pm 0.44^{\mathrm{b}}$ & $55.77 \pm 0.02^{\mathrm{a}}$ \\
Chroma (cooking pasta) & $12.05 \pm 0.57^{\mathrm{d}}$ & $34.68 \pm 0.47^{\mathrm{c}}$ & $41.87 \pm 0.91^{\mathrm{b}}$ & $44.71 \pm 0.27^{\mathrm{a}}$ \\
\hline
\end{tabular}

${ }^{1}$ The number after the letter $\mathrm{P}$ indicates the percentage (5\%, $10 \%$ or $\left.15 \%\right)$ substitution of wheat flour with pequi flour in pastas. ${ }^{2}$ Different letters in the same row indicate a significant difference at $5 \%$ significance using Tukey's test. ${ }^{3}$ Values expressed as mean \pm standard deviation.

Cooking times (Table 3) for treatments P15 (13.06 $\mathrm{min})$ and P10 (13.33 $\mathrm{min})$ were longer and statistically equal, followed by treatment P5 (11.67 $\mathrm{min})$ and the control (7.39 $\mathrm{min})$ with shorter times. These results indicate that the addition of pequi flour increased the cooking time of the pastas. Observing data from the literature, in a study with pastas in which wheat flour was partially replaced by chia flour (OLIVEIRA et al., 2015) and in another with gluten-free spaghetti based on sorghum, rice and potatoes (FERREIRA et al., 2016), the cooking times were high, as found here for pasta with pequi flour. Even so, it is understood that the advantages of replacing wheat flour with flours from some other vegetable species are in the differentiation of sensory characteristics and in the addition of nutritional and functional value to pastas (BIERNACKA et al., 2017; DEL BEM et al., 2012; KAUR et al., 2013; OLIVEIRA et al., 2015).

The control pasta did not differ from treatment P5, both presenting the lowest values of volume expansion when compared to pastas P15 (3.98 times) and P10 (4.03 times), which presented values significantly higher and equal to each other. For the variable water absorption, the highest value was obtained for formulation P10 (5.08\%), followed by P5 (4.64\%) and finally by P15 (4.01\%) and the control $(3.08 \%)$, the latter not differing statistically. In general, volume expansion is related to the absorption of water (OLIVEIRA et al., 2015; SURASANI et al., 2019); in fact, the results showed that the formulations $\mathrm{P} 10$ and $\mathrm{P} 5$ with pequi flour showed greater expansion of volume and greater water absorption, the same not happening for the P15 treatment. A possible explanation for the low water absorption of P15 may be that $15 \%$ pequi flour exceeded the limit for better water absorption by the pasta, because this flour had a visually larger granulometry than wheat flour and, according to Kaur et al. (2013), flours with larger grain sizes absorb less water than flours with finer particles. Thus, due to the swelling that occurs in the fibers (CUI et al., 2019), the expansion in volume of the pasta increased as the pequi flour content increased; however, inclusion of $15 \%$ pequi flour may have reduced excessively the amount of wheat flour and, therefore, there was little water absorption, in addition to a possible discontinuity in the gluten network, which reduces the water absorption capacity (PADALINO et al., 2015).

Studies by Piwinska et al. (2015) showed that pasta containing oat powder $(4 \%, 8 \%, 12 \%, 16 \%$ and $20 \%$ ) with a high fiber content had increased swelling rates (amount of water absorbed); the same occurred in pastas produced by Oliveira et al. (2015), which contained chia flour with $37.44 \%$ dietary fiber, presenting significantly higher water absorption and volume expansion than the values obtained for the control pasta; finally, pasta with $50 \%$ and $60 \%$ potato flour plus $10 \%$ oat, wheat or rice bran, which tends to have a higher fiber content, also showed higher water absorption than the control pasta (KRISHNAN et al., 2012). Thus, it is suggested that treatments with pequi (P5 and P10) 
showed this high expansion in volume possibly due to the high amount of dietary fiber in this fruit, from $16.18 \%$ to $31.37 \%$ on a dry basis (CORDEIRO et al., 2013; RIBEIRO et al., 2014), while refined wheat flour contains only $0.52 \%$ to $3.18 \%$ dietary fiber on a dry basis (CHANG; FLORES, 2004; VIEIRA et al., 2015).

For the variable cooking loss, formulations with pequi flour, P5 (9.55\%), P10 (11.00\%) and P15 (10.04\%), showed significantly higher values compared to the control $(5.91 \%)$. In addition, the possible increase in the pasta's fiber content due to the addition of pequi flour may have led to a situation similar to what occurred in the study by Padalino et al. (2015), who showed that whole wheat pasta with higher amounts of fiber had a greater loss of soluble solids (starch) compared to whole wheat pasta with a lower fiber content, and suggested that this may be a consequence of the interference of this nutrient in the starch and gluten network.

In agreement with our results, other studies with replacement of gluten-based flours by glutenfree flours also show this type of difference in the loss of soluble solids: $7.70 \%$ and $7.90 \%$ loss of soluble solids in pastas made from a mixture of wheat semolina with chickpeas and wheat semolina with peas, respectively, against only $4.00 \%$ loss in pasta containing only wheat semolina (DEL BEM et al., 2012); in pasta with substitution of $30 \%, 40 \%$ and $50 \%$ of wheat semolina for peanut flour the losses increased, being 5.96\%, 6.61\% and 7.27\%, respectively (HOWARD; HUNG; McWATTERS, 2011 ); and in pasta with a formulation of $70 \%$ sweet potato flour (two varieties) and $27 \%$ wheat flour the losses were $13.05 \%$ and $14.00 \%$ (KRISHNAN et al., 2012). Thus, it is believed that with an increase of pequi flour in the pasta, there was an increase in the fiber content, which caused this greater loss of product solids.

\section{Color analysis}

The incorporation of pequi flour directly influenced the color (difference in color and chroma) of the elaborated pasta.
For the first aspect, it was observed that the use of pequi flour made the color difference between the pasta before and after cooking more evident, since before cooking these pastas had more intense colors because of the carotenoid pigments of this fruit (VILAS BOAS et al., 2012; NASCIMENTO et al., 2017), and after cooking these became clearer. This is also explained by the absorption of water, since in dehydrated raw pasta the color becomes more visible and from the cooking and incorporation of water these characteristic color pigments are also diluted.

In the case of the chroma variable, the raw pasta with the highest purity or color saturation was treatment P15 (55.77), which differed statistically from the other treatments, P10 (45.27) and P5 (45.92), and the control with less saturation of color (17.99), that is, the treatments with pequi flour reflected in greater chromaticity. And even when the pastas were evaluated after cooking, the samples with pequi flour had more intense colors than the control sample, with P15 showing the highest chromaticity value.

Despite the dilution of carotenoids in the pasta after cooking and their probable partial degradation, it is noteworthy that the incorporation of ingredients with carotenoids in food formulations is nutritionally important, as they have several functions, such as anti-inflammatory and antioxidant properties, and prevention of cardiovascular and ocular diseases and some cancers (EGGERSDORFER; WYSS, 2018; WOODSIDE et al., 2015).

\section{Sensory analysis}

The data for acceptance and consumption intention tests are shown in Table 4 . The best results for consumption intention were found for treatments P15 (4.23) and P10 (4.28) with high scores between "I would eat occasionally" - grade 4 - and "I would eat often" - grade 5; followed by treatment P5 (3.63), and the control with the lowest score (3.16), the latter sitting between "I would rarely eat" - grade 3 - and "I would eat occasionally" - grade 4.

Table 4. Sensory analysis (consumption intention and acceptance tests) of pastas.

\begin{tabular}{cccccc}
\hline Test $^{1,2}$ & Attribute & Control & $\mathrm{P}^{3}$ & ${\mathrm{P} 10^{3}}^{3}$ & $\mathrm{P} 15^{3}$ \\
\hline Consumption intention & - & $3.16 \pm 1.74^{\mathrm{b}}$ & $3.63 \pm 1.78^{\mathrm{ab}}$ & $4.28 \pm 1.70^{\mathrm{a}}$ & $4.23 \pm 1.89^{\mathrm{a}}$ \\
Acceptance & Appearance & $4.62 \pm 2.48^{\mathrm{b}}$ & $6.12 \pm 2.07^{\mathrm{a}}$ & $6.64 \pm 1.83^{\mathrm{a}}$ & $6.43 \pm 1.98^{\mathrm{a}}$ \\
& Texture & $5.50 \pm 2.54^{\mathrm{b}}$ & $6.33 \pm 2.15^{\mathrm{ab}}$ & $6.90 \pm 1.92^{\mathrm{ab}}$ & $6.45 \pm 1.95^{\mathrm{a}}$ \\
& Flavor & $4.60 \pm 2.48^{\mathrm{b}}$ & $5.59 \pm 2.26^{\mathrm{ab}}$ & $6.34 \pm 2.07^{\mathrm{a}}$ & $6.10 \pm 2.33^{\mathrm{a}}$ \\
& Global evaluation & $4.79 \pm 2.35^{\mathrm{b}}$ & $5.78 \pm 1.88^{\mathrm{a}}$ & $6.52 \pm 1.82^{\mathrm{a}}$ & $6.26 \pm 1.98^{\mathrm{a}}$ \\
\hline
\end{tabular}

${ }^{1}$ Different letters in the same row indicate a significant difference at $5 \%$ significance using Tukey's test. ${ }^{2}$ Values expressed as mean \pm standard deviation. ${ }^{3}$ The number after the letter $\mathrm{P}$ indicates the percentage $(5 \%, 10 \%$ or $15 \%)$ substitution of wheat flour with pequi flour in pastas. 
The pastas produced with the highest levels of pequi flour showed higher scores for all attributes evaluated in the acceptance test. In summary, in terms of appearance, all treatments with pequi flour had scores higher than for the control pasta and were not significantly different from each other. For the texture attribute, sample P15 with a higher content of pequi flour was the best evaluated and differed statistically from the control sample. In terms of flavor, higher scores were obtained for samples P15 and P10 (higher concentration of pequi flour) than for the control pasta. And finally, in the global evaluation, the samples with pequi did not present significant differences between themselves, with higher marks than those attributed to the control pasta.

It is possible that the way of preparing the pasta had a strong influence on the sensory evaluation, resulting in not-so-high scores, because in the data collection questionnaire $71.93 \%$ of the participants stated that they prefer to consume pasta served with sauces (white, tomato, carbonara, Bolognese). However, even though the pastas in this work were served with no type of sauce, those made with higher concentrations of pequi pleased most of the tasters, since the pastas best evaluated in all acceptance criteria were P10 and P15, with marks between 6 - "I liked it slightly" - and 7 - "I liked it regularly". According to the questionnaire, $71.67 \%$ of the participants have the habit of consuming fruits from the Cerrado; this may represent one of the reasons why pequi formulations were more accepted and preferred. Although the questionnaire did not ask exactly about the consumption of pequi, to avoid the occurrence of an expectation error during the sensory evaluation, it is known that this is one of the main Cerrado fruits consumed in regional dishes (PINTO et al., 2016).

As in this work, the literature shows that the substitution of wheat flour or the addition of substances of different vegetable species in pasta can improve the sensory parameters of this product, or keep them elevated when the control pasta is already well evaluated. As an example, Armellini et al. (2018) showed that pasta plus saffron extract had higher acceptance scores than the control pasta for all evaluated parameters, while Biernacka et al. (2017) produced pasta with different concentrations of locust bean fiber, presenting scores statistically equal to that of the control pasta, which received an evaluation close to "I liked it extremely". Focusing on the sensory results disclosed for products made with pequi, Rodrigues et al. (2016) and Andrade et al. (2009) carried out work on developing seasoning tablets and buffalo mozzarella with pequi flavor, respectively; the formulations with higher percentages of pequi were classified as better or preferred by the evaluators, as happened in this work.

\section{CONCLUSIONS}

In nutritional terms, pequi flour decreased the moisture content of raw pastas, which is beneficial in terms of stable storage, and increased the content of mineral residues and lipids in the cooking pastas. From the technological aspect, pequi flour caused an expansion in volume and water absorption, in addition to more intense colors in raw and cooked pastas. With regard to the sensory issue, pasta with pequi showed higher acceptance and intention to consume. In view of these results, considering all nutritional, technological and sensory aspects, it is concluded that pastas with higher levels $(10 \%$ and $15 \%$ ) of pequi flour showed the best results, pequi being a promising product for the food industry that seeks healthy innovations and sensory quality.

\section{ACKNOWLEDGEMENTS}

The authors thank the Grupo de Estudos em Produtos de Panificação e Massas (GEPPAM), the Universidade Federal de Minas Gerais (UFMG), the Pró-Reitoria de Pesquisa (PRPq) of UFMG, the Conselho Nacional de Desenvolvimento Científico e Tecnológico (CNPq) and the Fundação de Amparo à Pesquisa do Estado de Minas Gerais (FAPEMIG) for financial and technological support.

\section{REFERENCES}

AACC - American Association of Cereal Chemist. Approved Methods. 10 ed. Saint Paul, SP: AACC, 2000. $1200 \mathrm{p}$.

AGUILAR, E. C. et al. Paradoxical effect of a pequi oil-rich diet on the development of atherosclerosis: balance between antioxidant and hyperlipidemic properties. Brazilian Journal of Medical and Biological Research, 45: 601-609, 2012.

ALVES, A. M. et al. Características físicas e nutricionais de pequis oriundos dos estados de Tocantins, Goiás e Minas Gerais. Brazilian Journal of Food Technology, 17: 198-203, 2014.

ANDRADE, L. T. A. et al. Avaliação sensorial de queijo mussarela de búfala temperado com pequi. Revista do Instituto de Laticínios Cândido Tostes, 61: 3-9, 2009.

AOAC - Association of Official Analytical Chemists. Official Methods of Analysis of AOAC International. (20nd ed.), Rockville, MD: AOAC International, 2016. $3172 \mathrm{p}$.

ARMELLINI, R. et al. Effect of saffron (Crocus 
sativus L.) enrichment on antioxidant and sensorial properties of wheat flour pasta. Food Chemistry, 254: 55-63, 2018

BIERNACKA, B. et al. Physical, sensorial, and antioxidant properties of common wheat pasta enriched with carob fiber. LWT - Food Science and Technology, 77: 186-192, 2017.

BLIGH, E. G.; DYER, W. J. A rapid method of total lipid extraction and purification. Canadian Journal Biochemistry and Physiology, 37: 911-917, 1959.

BRASIL. Ministério da Agricultura, Pecuária e Abastecimento (2005a). Instrução Normativa $n^{\circ} 8$, de 2 de junho de 2005. Regulamento Técnico de Identidade e Qualidade da farinha de trigo. Diário Oficial [da] República Federativa do Brasil, Poder executivo, Brasília, DF. Disponível em: < http:// sistemasweb.agricultura.gov.br/sislegis/action/ detalhaAto.do? method $=$ visualizarAtoPortalMapa\&chave $=80379093$ 7>. Acesso em: 01 mai. 2020.

BRASIL. Ministério da Saúde. Agência Nacional de Vigilância Sanitária (2005b). Resolução RDC $\mathrm{n}^{\circ}$ 263, de 22 de setembro de 2005. Regulamento técnico para produtos de cereais, amidos, farinhas e farelos. Diário Oficial [da] República Federativa do Brasil, Poder Executivo, Brasília, DF, 23 set. 2005. Disponível em: < http://portal.anvisa.gov.br/ documents/33916/394219/RDC 263 2005.pdf/ e9aa3580-f130-4eb5-91cb-8b8818bcf6b2>. Acesso em: 30. mar 2020.

BRASIL - Ministério da Saúde. Agência Nacional de Vigilância Sanitária (2005c). Resolução n 269, de 22 de setembro de 2005. Regulamento técnico sobre a Ingestão Diária Recomendada (IDR) de proteína, vitaminas e minerais. Diário Oficial [da] República Federativa do Brasil, Poder executivo, Brasília, DF, Disponível em: < http:// portal.anvisa.gov.br/documents/33916/394219/ RDC 269 2005.pdf/2e95553c-a482-45c3-bdd1-

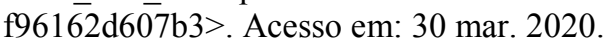

BRASIL - Ministério da Saúde. Resolução $n^{\circ}$ 54, de 12 de novembro de 2012 (2012). Regulamento técnico sobre Informação Nutricional Complementar. Diário Oficial [da] República Federativa do Brasil, Poder executivo, Brasília, DF, Disponível em: < http://portal.anvisa.gov.br/ documents/\%2033880/2568070/

rdc0054_12_11_2012.pdf/c5ac23fd-974e-4f2c-9fbc48f7e0a31864>. Acesso em: 30 mar. 2020.

CARDOSO, S. L. M. et al. Chemical characteristics and bioactive compounds of cooked pequi fruits
(Caryocar brasiliense Camb.) from the Brazilian Savannah. Fruits, 68: 3-14, 2013.

CHANG, Y. K.; FLORES, H. E. M. Qualidade tecnológica de massas alimentícias frescas elaboradas de semolina de trigo durum ( $T$. durum) e farinha de trigo ( $T$. aestivum). Ciência e Tecnologia de Alimentos, 24: 487-493. 2004.

CORDEIRO, M. W. S. et al. Características físicas, composição químico-nutricional e dos óleos essenciais da polpa de Caryocar brasiliense nativo do Estado de Mato Grosso. Revista Brasileira de Fruticultura, 35: 1127-1139, 2013.

CUI, J. et al. Dietary fibers from fruits and vegetables and their health benefits via modulation of gut microbiota. Comprehensive Reviews in Food Science and Food Safety, 18: 1514-1532, 2019.

DEL BEM, M. S. et al. Propriedades físico-químicas e sensoriais de massas alimentícias elaboradas com farinhas de leguminosas tratadas hidrotermicamente. Alimentos e Nutrição, 23: 101-110, 2012.

EGGERSDORFER, M.; WYSS, A. Carotenoids in human nutrition and health. Archives of Biochemistry and Biophysics, 652: 18-26, 2018.

FARVID, M. S. et al. Dietary linoleic acid and risk of coronary heart disease: A systematic review and meta-analysis of prospective cohort studies. Circulation, 130: 1568-1578, 2014.

FERREIRA, D. F. Estatística multivariada. Lavras, MG: UFLA, 2011. 661 p.

FERREIRA, S. M. R. et al. Utilization of sorghum, rice, corn flours with potato starch for the preparation of gluten-free pasta. Food Chemistry, 191: $147-151,2016$

FULLER, S. et al. New Horizons for the Study of Dietary Fiber and Health: A Review. Plant Foods for Human Nutrition, 71: 1-12, 2016.

GONÇALVES, G. A. S. et al. Qualidade dos frutos do pequizeiro submetidos a diferentes tempos de cozimento. Ciência e Agrotecnologia, 35: 377-385, 2011 .

GRAYSON, D. S. et al. Dietary omega-3 fatty acids modulate large-scale systems organization in the rhesus macaque brain. The Journal of Neuroscience, 34: 2065-2074, 2014.

HAN, S. F. et al. Lipolysis and thermogenesis in adipose tissues as new potential mechanisms for 
metabolic benefits of dietary fiber. Nutrition, 33: 118-124, 2017.

HOWARD, B. M.; HUNG, Y.; McWATTERS, K. Analysis of ingredient functionality and formulation optimization of pasta supplemented with peanut flour. Journal of Food Science, 76: 40-47, 2011.

IAL - Instituto Adolfo Lutz. Métodos químicos e físicos para análise de alimentos, 1. ed. digital. São Paulo, SP: Instituto Adolfo Lutz, 2008. 1020 p.

JUNQUEIRA, J. R. J. et al. Proximate composition and technological characteristics of dry pasta incorporated with micronized corn pericarp. Revista Caatinga, 30: 496-502, 2017.

KAUR, G. et al. Enrichment of pasta with different plant proteins. Journal of Food Science and Technology, 50: 1000-1005, 2013.

KHAN, I. et al. Acute effect of sorghum flourcontaining pasta on plasma total polyphenols, antioxidant capacity and oxidative stress markers in healthy subjects: A randomised controlled trial. Clinical Nutrition, 34: 415-421, 2015.

KORCZ, E.; KERÉNYI, Z.; VARGA, L. Dietary fibers, prebiotics, and exopolysaccharides produced by lactic acid bacteria: potential health benefits with special regard to cholesterol-lowering effects. Food \& Function, 9: 3057-3068, 2018.

KRISHNAN, J. G. et al. Evaluation of nutritional and physico-mechanical characteristics of dietary fiber-enriched sweet potato pasta. European Food Research and Technology, 234: 467-476, 2012.

LU, X. et al. Addition of mushroom powder to pasta enhances the antioxidant content and modulates the predictive glycaemic response of pasta. Food Chemistry, 264: 199-209, 2018.

MENDONÇA, K. S. et al. N. Influences of convective and vacum drying on the quality atributes of osmo-dried pequi (Caryocar brasiliense Camb.) slices. Food Chemistry, 224: 212-218, 2017.

MINGUITA, A. P. S. et al. Produção e caracterização de massas alimentícias a base de alimentos biofortificados: trigo, arroz polido e feijão carioca com casca. Ciência Rural, 45: 1895-1901, 2015.

MOREIRA, A. P. B. et al. Effect of a high-fat meal containing conventional or high-oleic peanuts on post-prandial lipopolysaccharide concentrations in overweight/obese men. Journal of Human Nutrition and Dietetics, 29: 95-104, 2016.
NASCIMENTO, N. R. R. et al. Antioxidant capacity of pequi (Caryocar brasiliense Camb.) pulp is preserved by freeze-drying and light-resistant packaging. Revista Brasileira de Fruticultura, 39: $1-9,2017$.

OLIVEIRA, M. R. et al. Evaluation of replacing wheat flour with chia flour (Salvia hispanica L.) in pasta. Semina: Ciências Agrárias, 36: 2545-2554, 2015 .

PADALINO, L. et al. Effect of raw material on cooking quality and nutritional composition of durum wheat spaghetti. International Journal of Food Sciences and Nutrition, 66: 266-274, 2015.

PASQUALONE. A. et al. Functional, textural and sensory properties of dry pasta supplemented with lyophilized tomato matrix or with durum wheat bran extracts produced by supercritical carbon dioxide or ultrasound. Food Chemistry, 213: 545-553, 2016.

PINTO, L. C. L. et al. Traditional knowledge and uses of the Caryocar brasiliense Cambess. (Pequi) by "quilombolas" of Minas Gerais, Brazil: subsidies for sustainable management. Brazilian Journal of. Biology, 76: 511-51, 2016.

PIWINSKA, M. et al. Hydration and physical properties of vacuum-dried durum wheat semolina pasta with high-fiber oat powder. LWT - Food Science and Technology, 63: 647-653, 2015.

REIS, D. S. et al. Produção e estabilidade de conservação de farinha de acerola desidratada em diferentes temperaturas. Brazilian Journal of Food Technology, 20: 1-7, 2017.

RIBEIRO, D. M. et al. Carotenoids are related to the colour and lipid content of the pequi (Caryocar brasiliense Camb.) pulp from the Brazilian Savanna. Food Science and Technology, 34: 507-512, 2014.

ROCHA, D. R. C. et al. Macarrão adicionado de orapro-nóbis (Pereskia aculeata Miller) desidratado. Alimentos e Nutrição, 19: 459-465, 2009.

RODRIGUES, E. F. et al. Development of bouillon cubes from souari nut pulp: formulation and physicochemical and sensorial evaluations. Brazilian Journal of Food Technology, 19: 1-8, 2016.

SANTOS, J. L. et al. Sensorial and physicochemical qualities of pasta prepared with amaranth. Acta Scientiarum, 37: 69-75, 2015.

SURASANI, V. K. R. et al. Functionality and cooking characteristics of pasta supplemented with protein isolate from pangas processing waste. LWT - 
Food Science and Technology, 111: 443-448, 2019.

THANDAPILLY, S. J. et al. Canola oil rich in oleic acid improves diastolic heart function in diet-induced obese rats. The Journal of Physiological Sciences, 67: 425-430, 2017.

VIEIRA, T. S. et al. Efeito da substituição da farinha de trigo no desenvolvimento de biscoitos sem glúten. Brazilian Journal of Food Technology, 18: 258$292,2015$.

VILAS BOAS, B. M. et al. Qualidade de pequis fatiados e inteiros submetidos ao congelamento. Ciência Rural, 42: 904-910, 2012.

WOODSIDE, J. V. et al. Carotenoids and health in older people. Maturitas, 80: 63-68, 2015. 